\title{
THE EFFECT OF COURSE, SYSTEM AND PERCEPTION ANTECEDENTS ON ADULT LEARNERS' BEHAVIOR
}

\author{
Hsiu-Li Liao, Chung Yuan Christian University, wenlly@im.cycu.edu.tw \\ Su-Houn Liu, Chung Yuan Christian University, vandy@im.cycu.edu.tw
}

\begin{abstract}
Compare to the continuous growth of the e-learning market for the lifelong learning of adults, there are relatively few studies are available on the learning behaviors of these learners on the e-learning website. In this study, TAM and TPB theory were integrated and employed to examine and predict adult learners' behavior in term of courses, systems and perception constructs. To test the research model, users from the SME Online University in Taiwan was chosen as a representative of e-learning users for the adult learning. Course flexibility, course quality, interaction with others, system functionality, system response, perceived usefulness, perceived ease of use and perceived behavioral control are positively related to adult learners' intention of continued use. Perceived usefulness, system functionality and course quality play the most important roles in predicting adult learners' intentions of continued use of the e-learning website. However, the number of the selected course and finished course are not related to adult learners' intention of continued use.
\end{abstract}

Keywords: Technology Acceptance Model (TAM), Planned Behavior Theory (TPB), Adult learning and continued use

\section{INTRODUCTION}

Lifelong learning is a term recognized that learning is not confined to childhood or the classroom, but takes place throughout life and in a range of situations. One of the most convenient delivery formats for lifelong learning is elearning [11]. The US market for Self-paced eLearning will projected to grow to $\$ 23.8$ billion by 2014 according to a new report by Ambient Insight. The demand for online education products in America is growing by 7.4\% [3]. Business spending on e-learning is expected to reach approximately \$19.6 billion by 2010, according to IDC [10]. However, compare to the continuous growth of the e-learning market for the lifelong learning of adults, there are relatively few studies are available on the learning behaviors of these learners on the e-learning website.

Richness research has presented e-learning potential for increasing learning effectiveness and learner satisfaction [6,7]. Previous research done under different task environments has suggested a variety of factors affecting user satisfaction with e-Learning. These factors that affecting students' satisfaction of using e-learning can categorized into six dimensions: student, teacher, course, technology, system design, and environment dimension $[4,16]$. On a preliminary study, after interviewing 40 lifelong learners, the researchers have identified that the student, teacher, course, and technology dimensions, including course flexibility, course quality, perceived interaction with others, system functionality, system response, perceived usefulness, perceived ease of use and perceived behavioral control, are the major factors that influence the continued use of e-learning for these learners [13].

For research in technology adoption, the technology acceptance model (TAM) has received considerable attention. This model proposes two key beliefs in the adoption of technology: perceived usefulness (PU) and perceived ease of use (PEU). Perceived ease-of-use and perceived usefulness have played important roles in affecting e-learning adoption decisions [14]. Some influential theories in other areas, such as theory of planned behavior (TPB) were borrowed into the studies of technology adoption. TPB is an extension of the theory of reasoned action made necessary by the original model's limitations in dealing with behaviors over which people have incomplete volitional control [1].

Perceived behavioral control (PBC) refers to one's perceived ease of performing a behavior, taking into account their personal resources (abilities, skills and knowledge) and situational variables (obstacles and opportunities) to 
predict behavior directly [2]. For example, when conducting lifelong learning, learners may need not only more resources (time, information, etc.), but also more self-confidence in making a proper decision. Therefore, the study integrates PBC into TAM antecedents to predict adult learners' behavior of continued using e-learning website. The definitions of the constructs are provided in Table 1.

Table 1. Research Variables and Definitions

\begin{tabular}{|l|l|c|}
\hline \multicolumn{1}{|c|}{ Research variables } & \multicolumn{1}{|c|}{ Definitions } & Reference \\
\hline Course Flexibility & $\begin{array}{l}\text { Degree to which taking the class on the lifelong e-learning } \\
\text { website allowed me to arrange my work for the class more } \\
\text { effectively. }\end{array}$ & {$[4,16]$} \\
\hline Course Quality & $\begin{array}{l}\text { Degree to which I am satisfied with the design and quality of } \\
\text { course content on the lifelong e-learning website. }\end{array}$ & {$[4,16]$} \\
\hline Interaction with others & $\begin{array}{l}\text { Degree to which student-to-student interaction on the lifelong e- } \\
\text { learning website was easier than in traditional courses. }\end{array}$ & {$[4,16]$} \\
\hline System Functionality & $\begin{array}{l}\text { Degree to which the lifelong e-learning website allows learner } \\
\text { control over his or her learning activity. }\end{array}$ & {$[15]$} \\
\hline System Response & $\begin{array}{l}\text { Degree to which the response time of the lifelong e-learning } \\
\text { website is reasonable. }\end{array}$ & {$[15]$} \\
\hline Perceived Usefulness & $\begin{array}{l}\text { Degree to which an innovation is considered as superior to its } \\
\text { predecessor }\end{array}$ & {$[9,15]$} \\
\hline Perceived Ease of Use & $\begin{array}{l}\text { Degree to which an innovation is considered by a learner as } \\
\text { relatively easy to use and understand }\end{array}$ & {$[9,15]$} \\
\hline $\begin{array}{l}\text { Perceived Behavioral } \\
\text { Control }\end{array}$ & $\begin{array}{l}\text { Degree to which I had the resources, knowledge, and ability to } \\
\text { use the lifelong e-learning website. }\end{array}$ & {$[1,12]$} \\
\hline $\begin{array}{l}\text { Intention of Continued } \\
\text { Use }\end{array}$ & $\begin{array}{l}\text { Degree to which a learner with prior experience of e-learning } \\
\text { intends to switch over to the innovation or increases his use in } \\
\text { the future }\end{array}$ & {$[1,12]$} \\
\hline
\end{tabular}

The hypotheses addressing adult e-learning behavior are as stated below.

H1: Course flexibility, course quality, interaction with others, system functionality and system response are positively related to user's perceived usefulness.

H2: Perceived ease of use is positively related to perceived usefulness.

H3: Course flexibility, course quality, interaction with others, system functionality and system response are positively related to user's perceived ease of use.

H4: Course flexibility, course quality, interaction with others, system functionality and system response are positively related to user's perceived behavioral control.

H5: Course flexibility, course quality, interaction with others, system functionality, system response, perceived usefulness, perceived ease of use and perceived behavioral control are positively related to user's selected course number.

H6: Course flexibility, course quality, interaction with others, system functionality, system response, perceived usefulness, perceived ease of use and perceived behavioral control are positively related to user's finished course number. 
H7: Course flexibility, course quality, interaction with others, system functionality, system response, perceived usefulness, perceived ease of use, perceived behavioral control, selected course number and finished course number are positively related to user's intention of continued use.

\section{RESEARCH METHODOLOGY}

\section{Characteristics of the Sample and Study Context}

To test the research hypotheses, users from the SME Online University (http://www.smelearning.org.tw) in Taiwan was chosen as a representative of e-learning users for the lifelong learning. The SME Online University has been recognized as the first e-learning website developed for small and medium enterprises (SME) in Asia and one of the biggest in the world. There are now more than 800 free online courses in five major categories. Today, the SME Online University has served over 300,000 SME employers and employees around the world. 500 subjects were randomly selected from the members of SME Online University. A total of 166 surveys were voluntarily completed, resulting in a response rate of 33.2\%. The age range of the sample was 20-50 years old (Table 1). Of the 166 respondents, 79 were females (48\%) and 87 were males (52\%).

\section{Instrument Development}

The survey questionnaire included a combination of items derived from earlier studies and newly developed items. Arbaugh [4] and Sun et al. [16] questionnaire items of course flexibility, course quality and interaction with others, Pituch and Lee [15] questionnaire items of system functionality and system response as well as Lee [12] questionnaire items of Perceived behavioral control was used in this study. Additionally, perceived usefulness, perceived ease of use and adult learners' intention to continued use were following the recommendations of Davis et al. [9] as the foundation for the development of the survey instrument. Respondents scored on a seven-point Likerttype scale with the end points being "strongly disagree" and "strongly agree", except for items intended to collect demographic data.

\section{ANALYSIS AND RESULTS}

\section{Measures}

The constructs of reliability and validity of the instrument were evaluated. Table 2 shows the number of items comprising each scale and Cronbach's alpha for scale reliability obtained for the samples. Factor reliabilities, as represented by Cronbach's alpha in Table 2, were between 0.771 and 0.949 for each factor. Reliability from the sample showed a reasonable level of reliability $(\mathrm{a}>0.70)$ [8].

Table 2. Construct Means, Standard Deviations and Reliabilities

\begin{tabular}{|l|c|c|c|c|}
\hline \multicolumn{1}{|c|}{ Construct } & $\begin{array}{c}\text { Number of } \\
\text { Items }\end{array}$ & Mean & $\begin{array}{c}\text { Standard } \\
\text { Deviation }\end{array}$ & $\begin{array}{c}\text { Cronbach } \\
\text { Alpha }\end{array}$ \\
\hline 1. Course Flexibility (CF) & 3 & 5.831 & 1.248 & 0.771 \\
\hline 2. Course Quality (CQ) & 3 & 5.211 & 1.259 & 0.839 \\
\hline 3. Interaction with others (PIO) & 2 & 3.807 & 1.517 & 0.860 \\
\hline 4. System Functionality (SF) & 3 & 5.725 & 1.158 & 0.868 \\
\hline 5. System Response (SR) & 3 & 4.996 & 1.328 & 0.930 \\
\hline 6. Perceived Usefulness (PU) & 4 & 5.700 & 1.128 & 0.943 \\
\hline 7. Perceived Ease of Use (PE) & 4 & 5.772 & 1.097 & 0.948 \\
\hline 8. Perceived Behavioral Control (PBC) & 3 & 5.757 & 1.133 & 0.949 \\
\hline 9. Intention of Continued Use (ICU) & 3 & 5.916 & 1.125 & 0.862 \\
\hline
\end{tabular}


Factor analysis also confirmed that the construct validity of the scales could be measured adequately. Using the principal components method with varimax rotation, construct validity was examined. Table 3 reports the factor loadings for each of the factors items. Bagozzi and Yi [5] suggested that factor loadings for each item should be over 0.6 to be valid. The factor loadings for all items exceeded 0.8 in this study. All item loadings for each construct were greater than crossloadings of that construct with all other constructs. Hence, convergent validity and discriminant validity were adequate.

Pearson correlation coefficients for all research variables are shown with significance (alpha) set at 0.05 in Table 4. Course flexibility $(r=0.628, p<0.01)$, course quality $(r=0.737, p<0.01)$, interaction with others $(r=0.254, p<$ $0.01)$, system functionality $(\mathrm{r}=0.772, \mathrm{p}<0.01)$, system response $(\mathrm{r}=0.637, \mathrm{p}<0.01)$ and perceived ease of use $(\mathrm{r}=$ $0.735, \mathrm{p}<0.01)$ are positively related to perceived usefulness. Therefore, H1 and H2 are supported. System functionality, course quality, perceived ease of use, system response and course flexibility are the major factors influencing the perceived usefulness. When adult learners perceived that the e-learning website can present course material in well-organized and meet their needs, they find it is useful to enhance their effectiveness to accomplish learning tasks.

Table 3. Factor Loadings and Cross-Loadings

\begin{tabular}{|c|c|c|c|c|c|c|c|c|c|}
\hline & $\mathrm{CF}$ & CQ & $\mathrm{IO}$ & SF & SR & $\mathrm{PU}$ & $\mathrm{PE}$ & PBC & INT \\
\hline \multirow[t]{3}{*}{ CF } & 0.8249 & 0.5043 & 0.1943 & 0.5186 & 0.5216 & 0.5349 & 0.6340 & 0.6135 & 0.5584 \\
\hline & 0.8745 & 0.5298 & 0.1314 & 0.5966 & 0.4279 & 0.5748 & 0.4910 & 0.4800 & 0.5558 \\
\hline & 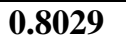 & 0.4989 & 0.0240 & 0.5416 & 0.3525 & 0.4894 & 0.4941 & 0.4809 & 0.5711 \\
\hline \multirow[t]{3}{*}{ CQ } & 0.5504 & 0.8519 & 0.1300 & 0.6043 & 0.3647 & 0.6003 & 0.5114 & 0.4522 & 0.5633 \\
\hline & 0.5119 & 0.8895 & 0.1938 & 0.6686 & 0.3794 & 0.6754 & 0.5434 & 0.4591 & 0.6300 \\
\hline & 0.5460 & 0.8819 & 0.2366 & 0.7203 & 0.6167 & 0.6735 & 0.7062 & 0.5583 & 0.5977 \\
\hline \multirow[t]{2}{*}{ IO } & 0.1672 & 0.1981 & 0.9310 & 0.1510 & 0.2673 & 0.2128 & 0.1758 & 0.1129 & 0.1814 \\
\hline & 0.1132 & 0.2094 & 0.9534 & 0.1277 & 0.3073 & 0.2546 & 0.2342 & 0.1306 & 0.2339 \\
\hline \multirow[t]{3}{*}{ SF } & 0.5677 & 0.5784 & 0.0609 & 0.8437 & 0.4471 & 0.6173 & 0.6101 & 0.5601 & 0.5668 \\
\hline & 0.5834 & 0.7187 & 0.1401 & 0.9202 & 0.4867 & 0.7130 & 0.6271 & 0.5465 & 0.6609 \\
\hline & 0.6196 & 0.7415 & 0.1849 & 0.9186 & 0.5629 & 0.7374 & 0.6920 & 0.5997 & 0.6710 \\
\hline \multirow[t]{3}{*}{ SR } & 0.5055 & 0.5095 & 0.3498 & 0.5605 & 0.9357 & 0.6130 & 0.6311 & 0.5492 & 0.4252 \\
\hline & 0.4938 & 0.4716 & 0.2853 & 0.4991 & 0.9456 & 0.6078 & 0.6467 & 0.5475 & 0.4182 \\
\hline & 0.4906 & 0.5055 & 0.2299 & 0.5242 & 0.9464 & 0.5790 & 0.6391 & 0.5377 & 0.4326 \\
\hline \multirow[t]{4}{*}{ PU } & 0.5926 & 0.6994 & 0.2496 & 0.7337 & 0.6224 & 0.9307 & 0.7044 & 0.6356 & 0.6636 \\
\hline & 0.5309 & 0.6587 & 0.2566 & 0.7099 & 0.5847 & 0.9026 & 0.7139 & 0.6084 & 0.6475 \\
\hline & 0.6215 & 0.6842 & 0.2206 & 0.7011 & 0.5827 & 0.9225 & 0.6750 & 0.6558 & 0.6839 \\
\hline & 0.5923 & 0.7091 & 0.2268 & 0.7317 & 0.5864 & 0.9504 & 0.7281 & 0.6065 & 0.6961 \\
\hline \multirow[t]{4}{*}{$\mathrm{PE}$} & 0.6061 & 0.5650 & 0.1219 & 0.6426 & 0.5764 & 0.6797 & 0.8933 & 0.7825 & 0.6068 \\
\hline & 0.5762 & 0.5843 & 0.1166 & 0.6163 & 0.5825 & 0.6529 & 0.8669 & 0.7358 & 0.5821 \\
\hline & 0.6296 & 0.6765 & 0.2563 & 0.7084 & 0.6733 & 0.7384 & 0.9802 & 0.7042 & 0.6455 \\
\hline & 0.6191 & 0.5865 & 0.1335 & 0.6255 & 0.6497 & 0.6683 & 0.8922 & 0.7835 & 0.5783 \\
\hline \multirow[t]{3}{*}{ PBC } & 0.5313 & 0.5089 & 0.1700 & 0.5456 & 0.5309 & 0.5949 & 0.7571 & 0.8703 & 0.5960 \\
\hline & 0.6155 & 0.5046 & 0.0890 & 0.6115 & 0.5086 & 0.6286 & 0.7407 & 0.9484 & 0.6519 \\
\hline & 0.6355 & 0.5786 & 0.1428 & 0.6386 & 0.5980 & 0.6862 & 0.7660 & 0.9913 & 0.6579 \\
\hline \multirow[t]{3}{*}{ ICU } & 0.6621 & 0.6259 & 0.1826 & 0.6684 & 0.3956 & 0.6944 & 0.6250 & 0.6700 & 0.9681 \\
\hline & 0.5899 & 0.6095 & 0.3311 & 0.6172 & 0.4276 & 0.6570 & 0.5924 & 0.5804 & $\mathbf{0 . 8 7 1 3}$ \\
\hline & 0.5472 & 0.6448 & 0.1765 & 0.6394 & 0.4478 & 0.6311 & 0.5919 & 0.5015 & 0.8489 \\
\hline
\end{tabular}


Course flexibility ( $r=0.647, \mathrm{p}<0.01)$, course quality $(\mathrm{r}=0.640, \mathrm{p}<0.01)$, interaction with others $(\mathrm{r}=0.167, \mathrm{p}<$ $0.05)$, system functionality $(r=0.692, p<0.01)$, and system response $(r=0.665, p<0.01)$ are positively related to perceived ease of use. H3 thus are supported. System functionality and system response plays the more important roles in affecting perceived ease of use. When the e-learning website with well-organized and readable format materials can allow learners to control over their learning activity and the response time is reasonable, the adult learners can perceive it is easy to operate the website to learn.

Course flexibility $(\mathrm{r}=0.615, \mathrm{p}<0.01)$, course quality $(\mathrm{r}=0.550, \mathrm{p}<0.01)$, system functionality $(\mathrm{r}=0.622, \mathrm{p}<$ $0.01)$, and system response $(\mathrm{r}=0.569, \mathrm{p}<0.01)$ are positively related to perceived behavioral control. However, interaction with others $(r=0.140, p>0.05)$ are not related to perceived behavioral control. H4 are partially supported. System functionality and course flexibility are more important factor than others. When the e-learning website with well-organized and readable format materials can allow learners to control over their learning activity via the Internet and arrange my learning schedule anytime, the learners can perceive they would be able to use the lifelong e-learning website well for learning process.

Course flexibility $(r=0.659, \mathrm{p}<0.01)$, course quality $(\mathrm{r}=0.691, \mathrm{p}<0.01)$, interaction with others $(\mathrm{r}=0.249, \mathrm{p}<$ $0.01)$, system functionality $(r=0.708, p<0.01)$, system response $(r=0.469, p<0.01)$, perceived usefulness $(r=$ 0.722, $\mathrm{p}<0.01)$, perceived ease of use $(\mathrm{r}=0.637, \mathrm{p}<0.01)$ and perceived behavioral control $(\mathrm{r}=0.636, \mathrm{p}<0.01)$ are positively related to intention of continued use. H7 are thus supported. Perceived usefulness and system functionality play the most significant roles in influencing learners' intention of continued use. When adult learners find the e-learning website is useful and with well-organized and readable format materials, they would frequently use the lifelong e-learning website in the future and strongly recommend that others use the lifelong e-learning website.

The numbers of selected courses $(r=0.063, p>0.05)$ and finished courses $(r=-0.125, p>0.05)$ are not related to intention of continued use. Finished courses number is positively related to selected courses number $(r=0.532, p<$ 0.01). However, all constructs are not significantly related to selected courses number and finished courses number. Therefore, H5 and H6 are not supported.

Table 4. Pearson Correlation Coefficients

\begin{tabular}{|c|c|c|c|c|c|c|c|c|c|c|c|}
\hline & CF & CQ & IO & SF & SR & PU & PE & PBC & ICU & SC & FC \\
\hline CF & 1 & & & & & & & & & & \\
\hline CQ & $0.613^{* *}$ & 1 & & & & & & & & & \\
\hline IO & 0.147 & $0.213^{* *}$ & 1 & & & & & & & & \\
\hline SF & $0.661^{* *}$ & $0.759^{* *}$ & 0.148 & 1 & & & & & & & \\
\hline SR & $0.524^{* *}$ & $0.519^{* *}$ & $0.302^{* *}$ & $0.559^{* *}$ & 1 & & & & & & \\
\hline PU & $0.628^{* *}$ & $0.737^{* *}$ & $0.254^{* *}$ & $0.772^{* *}$ & $0.637^{* *}$ & 1 & & & & & \\
\hline PE & $0.647^{* *}$ & $0.640^{* *}$ & $0.167^{*}$ & $0.692^{* *}$ & $0.665^{* *}$ & $0.735^{* *}$ & 1 & & & & \\
\hline PBC & $0.615^{* *}$ & $0.550^{* *}$ & 0.140 & $0.622^{* *}$ & $0.569^{* *}$ & $0.662^{* *}$ & $0.823^{* *}$ & 1 & & & \\
\hline ICU & $0.659^{* *}$ & $0.691^{* *}$ & $0.249^{* *}$ & $0.708^{* *}$ & $0.469^{* *}$ & $0.722^{* *}$ & $0.637^{* *}$ & $0.636^{* *}$ & 1 & & \\
\hline SC & -0.020 & -0.011 & -0.045 & 0.006 & 0.046 & 0.061 & -0.005 & -0.021 & 0.063 & 1 & \\
\hline FC & -0.076 & 0.001 & -0.016 & -0.024 & -0.068 & -0.019 & -0.054 & -0.086 & -0.125 & $0.532^{* *}$ & 1 \\
\hline
\end{tabular}

SC: Selected Courses Number

FC: Finished Courses Number

* Correlation is significant at the 0.05 level 


\section{Issues in Information Systems}

Volume XII, No. 2, pp 223-230, 2011

** Correlation is significant at the 0.01 level

\section{CONCLUSIONS}

Course flexibility, course quality, interaction with others, system functionality, system response, perceived usefulness, perceived ease of use and perceived behavioral control are positively related to adult learners' intention of continued use. Perceived usefulness, system functionality and course quality play the most important roles in predicting adult learners' intentions of continued use of the e-learning website. Our findings have indicated that when adult learners perceived the courses can improve their work/learning performance and course materials in a well-organized and readable format, adult learners will frequently use the e-learning website in the future, they will increase the intention of continued use in the future.

However, the number of the selected course and finished course are not related to adult learners' intention of continued use. The researchers of this study believed that this has indicated a unique learning behavior of the adult learning on the Internet. For these adult learners on the SME University, they usually come to the website with a mission, that is, they come to learn specific knowledge that they need. Our research data has indicated that it is some learners with limited number (not the highest number) of the selected course and finished course have the highest intention of continued use. Our explanation is that they are learners that have just came to the website and begun their learning process, thus they can have the highest intention to continued use. Even though the learners might have highly satisfy with the service of the website throughout their learning process, still, their intention to continue use will drop after their learning have came to an end.

The current research can lead to several limitation and further studies. First, the dependent construct here represents adult learners' selected course, finished course and behavioral intention of continued use. It would be valuable that studies can be conducted to understand other learners' actual behaviors. A second concern is that the data collected and tested here has been empirically assessed in only one conducting context. The gereralizability of the results reported here is not known beyond the current sample, e-learning context and other antecedents. Based on this understanding, website manager and education institution can determine how to improve the learners' intention of continued use and actual usage of e-learning websites.

\section{REFERENCES}

1. Ajzen, I. (1991). The theory of planned behavior. Organizational Behavior and Human Decision Processes, 50, 179-211.

2. Ajzen, I. and Madden, T. J. (1986). Prediction of goal directed behavior: attitudes, intentions, and perceived behavioral control. Journal of Experimental Social Psychology, 22, 453-474.

3. Anonymous (2009). Ambient insight reports strong us elearning market. Business Wire.

4. Arbaugh, J. B. (2002). Managing the on-line classroom: a study of technological and behavioral characteristics of web-based mba courses. Journal of High Technology Management Research, 13, 203-223.

5. Bagozzi, R. P., \& Yi, Y. (1988). On the evaluation of structure equations models. Academic of Marketing Science, 16, 76-94.

6. Chang, S. C. and Tung, F. C. (2008). An empirical investigation of students' behavioural intentions to use the online learning course websites, British Journal of Educational Technology, 39(1), 71-83.

7. Chu, J. C. (2010). How family support and internet self-efficacy influence the effects of e-learning among higher aged adults - analyses of gender and age differences. Computers \& Education, 55(1), 255-264.

8. Cronbach, L. J. (1970). Essentials of psychological testing. New York: Harper and Row.

9. Davis, F.D., Bagozzi, R.P. and Warshaw, P.R. (1989). User acceptance of computer technology: a comparison of two theoretical models. Management Science, 35(8), 982-1003

10. Fretty (2006). Go the distance. PM Network, 20(9), 16-21.

11. Lamont, J. (2008). E-learning: options for delivery. KM World, 17(5), 22-23.

12. Lee, M.C. (2010). Explaining and Predicting Users' Continuance Intention toward E-Learning: An Extension of the Expectation-Confirmation Model. Computers \& Education, 54(2), 506-516. 
13. Liao, H. L. and Chou, Y. J. (2010). Factors Influencing Adult Learners' Continued Use of E-Learning. 2010 Information Management Research and Application Conference (IMRAC) proceeding.

14. Liu, S. H., Liao, H. L. and Pratt, J. A. (2009). Impact of media richness and flow on e-learning technology acceptance. Computers \& Education, 52, 599-607.

15. Pituch, K.A. and Lee, Y.K. (2006). The influence of system characteristics on e-learning use. Computers \& Education, 47, 222-244

16. Sun, P. C., Tsai, R. J., Finger, G., Chen Y. Y. and Yeh, D. (2008). What drives a successful e-learning? an empirical investigation of the critical factors influencing learner satisfaction. Computers \& Education, 50, 11831202. 


\section{Issues in Information Systems}

Volume XII, No. 2, pp 223-230, 2011

\section{APPENDIX: ITEMS AND SCALES}

Course Flexibility (Arbaugh, 2000; Sun et al., 2008)

1. Taking this class via the Internet allowed me to arrange my work for the class more effectively.

2. Taking this class via the Internet allowed me to arrange my work schedule more effectively.

3. Taking this class via the Internet allowed me to take a class I would otherwise have to miss.

Course Quality (Self-developed)

4. The level of the course difficulty is appropriate on the lifelong e-learning website.

5. The course contents on the lifelong e-learning website meet my needs.

6 . I am satisfied with the design and quality of course content on the lifelong e-learning website

Interaction with Others (Arbaugh, 2000; Sun et al., 2008)

7. Student-to-student interaction on the lifelong e-learning website was more difficult than in traditional courses. (R)

8. Interacting with other students and the instructor using the lifelong e-learning website became more natural as the course progressed.

System Functionality (Pituch and Lee, 2006)

9. The lifelong e-learning website allows learner control over his or her learning activity.

10. The lifelong e-learning website offers multimedia (audio, video, and text) types of course content.

11. The lifelong e-learning website can present course material in a well-organized and readable format

System Response (Pituch and Lee, 2006)

12. When you are using the Web-based learning system, system response is fast.

13. In general, the response time of the lifelong e-learning website is consistent.

14. In general, the response time of the lifelong e-learning website is reasonable.

Perceived Usefulness (Davis, 1989; Pituch and Lee, 2006)

15. Using the lifelong e-learning website will allow me to accomplish learning tasks more quickly.

16. Using the lifelong e-learning website will improve my learning performance.

17. I find the lifelong e-learning website useful in my learning.

18. Using the lifelong e-learning website will enhance my effectiveness in learning.

Perceived Ease of Use (Davis, 1989; Pituch and Lee, 2006)

19. Learning to operate the lifelong e-learning website is easy for me.

20. My interaction with the lifelong e-learning website is clear and understandable.

21. I believe it would be easy to get the lifelong e-learning website to do what I want it to do.

22. Learning to use the lifelong e-learning website would be easy for me.

Perceived Behavioral Control (Ajzen, 1991; Lee, 2010)

26. Using the lifelong e-learning website was entirely within my control.

27. I had the resources, knowledge, and ability to use the lifelong e-learning website.

28. I would be able to use the lifelong e-learning website well for learning process.

Intention of Continued Use (Davis, 1989; Lee, 2010)

29. I will use the lifelong e-learning website on a regular basis in the future.

30. I will frequently use the lifelong e-learning website in the future.

31. I will strongly recommend that others use the lifelong e-learning website. 